\title{
Effect of the implementation of the Hazard Analysis Critical Control Point (HACCP) prerequisite program in an institutional foodservice unit in Southern Brazil
}

\author{
Efeito da implementação do programa pré requisitos para Análise de Perigos e Pontos Críticos de Controle
} (APPCC) em um serviço de alimentação institucional do sul do Brasil

\author{
Kelly Lameiro RODRIGUES ${ }^{1,2 *}$, Jorge Adolfo SILVA¹, José Antonio Guimarães ALEIXO²
}

\begin{abstract}
The aims of this study were to investigate the hygienic practices in the food production of an institutional foodservice unit in Southern Brazil and to evaluate the effect of implementing good food handling practices and standard operational procedures using microbiological hygiene indicators. An initial survey of the general operating conditions classified the unit as regular in terms of compliance with State safety guidelines for food service establishments. An action plan that incorporated the correction of noncompliance issues and the training of food handlers in good food handling practices and standard operational procedures were then implemented. The results of the microbiological analysis of utensils, preparation surfaces, food handlers' hands, water, and ambient air were recorded before and after the implementation of the action plan. The results showed that the implementation of this type of practice leads to the production of safer foods.
\end{abstract}

Keywords: catering services; microbiological food quality; HACCP.

\section{Resumo}

O objetivo deste estudo foi investigar as práticas de higiene na produção de alimentos em um serviço de alimentação do Sul do Brasil, e avaliar o efeito da aplicação das Boas Práticas de Manipulação e Procedimentos Operacionais Padronizados utilizando indicadores microbiológicos de qualidade de higiene. Um levantamento inicial sobre as condições de funcionamento geral classificou a unidade como regular em relação ao cumprimento das diretrizes de segurança do Estado para os estabelecimentos de produção de alimentos. Foi implementado um plano de ação que incorporou a correção das questões de não-conformidade e a formação dos manipuladores de alimentos sobre boas práticas alimentares manipulação e Procedimentos Operacionais Padronizados. Os resultados das análises microbiológicas realizadas em utensílios, superfícies de manipulação de alimentos, mãos de manipuladores de alimentos, água e ar foram registrados antes e depois da implementação do plano de ação. Os resultados mostraram que a aplicação deste tipo de intervenção leva à produção de alimentos seguros.

Palavras-chave: serviços de alimentação; qualidade microbiológica de alimentos; APPCC.

\section{Introduction}

The habit of having meals at home has been replaced with eating away from home due to changes occurring in modern society, such as a growing number of working women and large urban centers, which has generated a significant increase in the number of mass catering establishments (OLIVEIRA et al., 2005).

Institutional foodservice units, which are establishments dedicated to the production and service of meals for healthy people, are an important part of the catering industry. Epidemiological data shows that institutional food service units are one of the main establishments involved in outbreaks of foodborne diseases and that the causative factors are directly related to the production process and improper food handling practices (CARMO, 2008; WORLD..., 2008).
Catering companies require continuous control over the production process, from the initial selection of food items up to the final stages of meal distribution and service, to be able to ensure the production of safe foods. Food safety is directly affected by the use of good food handling practices and standardized operational procedures, which are part of the prerequisite programs for implementation of the Hazard Analysis Critical Control Point (HACCP), system of safe food production (CODEX..., 1997).

The objectives of this study were to investigate the hygienic practices of an institutional foodservice unit in Southern Brazil and to investigate whether microbiological indicators of good hygienic practices improved after the implementation of a training program on safe handling practices and standard operational procedures.

\footnotetext{
Received $1 / 10 / 10$

Accepted 12/10/11 (005090)

1 School of Agronomy Eliseu Maciel, Federal University of Pelotas - UFPel, CP 354, Pelotas, RS, Brazil, e-mail: lameiro_78@hotmail.com

2 School of Nutrition, Federal University of Pelotas - UFPel, Rua Gomes Carneiro, 1, Centro, CEP 96010-610, Pelotas, RS, Brazil

${ }^{*}$ Corresponding author
} 


\section{Materials and methods}

The study was conducted in two phases in an institutional food service unit in Pelotas, a major city in the south region of Brazil, known as the "City of Food". Phase 1 consisted of an evaluation of the general working conditions through visual observation, a survey using a questionnaire, and a collection of samples for microbiological analyses. Phase 2 included the implementation of corrective steps to ensure conformity with the guidelines highlighted in Phase 1, training food handlers on good food handling practices, standardization of operational procedures, and further microbiological analyses to determine the efficacy of the implemented changes.

\subsection{Questionnaire}

Initially, a questionnaire was developed and conducted to evaluate existing hygienic-sanitary working practices and the compliance with state safety guidelines for food service establishments (RIO GRANDE DO SUL, 2009). Data collection was conducted through direct on-site observation, interviews with a nutritionist, and unit documentation. According to compliance with regulatory items evaluated in the questionnaire, food service units were rated 'good' (over 75\% compliance); 'regular' (51-75\% compliance); and 'poor' (below 50\% compliance).

\subsection{Microbiological analysis}

Samples for microbiological tests were collected for four consecutive weeks in the two phases of the study: The first sampling period occurred immediately after conducting the questionnaire (Phase 1), and the second after training and implementation of standardized good practices and operational procedures (Phase 2). The methodology used in the microbiological analysis was that recommended in the Bacteriological Analytical Manual (BENNETT; LANCETTE, 1998; HITCHINS et al., 1998; MAURIN; PEELER, 1998; TOURNAS et al., 1998).

After collection, samples were transported in isothermal containers to the laboratory where analyses started upon arrival.

\subsection{Equipment and food handling surfaces}

Mesophilic aerobic bacteria, coliforms at $35^{\circ} \mathrm{C}$, and yeast and mold counts were made to evaluate the hygienic-sanitary conditions of equipment and food handling surfaces. Samples were collected from $100 \mathrm{~cm}^{2}$ of meat cutting boards $(\mathrm{n}=3)$, vegetables cutting boards $(n=3)$, large $(n=5)$ and medium $(\mathrm{n}=5)$ pans; and from $300 \mathrm{~cm}^{2}$ of the food pre-preparation $(n=2)$ and preparation $(n=3)$ table surfaces. There were a total of 21 samples collected in each phase. The samples were collected using the 'swab method' (SVEUM et al., 1992) immediately after the hygienization procedure.

\subsection{Food handlers' hands}

In each study phase, both the right and left hands of 19 food handlers were swabbed immediately after washing. Colonies of coagulase-positive Staphylococcus aureus and coliforms were counted to evaluate the extent of contamination of their hands.

\subsection{Water}

Microbiological quality of the water used in the food service unit was assessed in 16 samples in each phase of the study. Each sample of $100 \mathrm{~mL}$ was collected in sterile containers with sodium thiosulfate. Colony counts of mesophilic aerobic bacteria and the presence/absence of coliforms at $35^{\circ} \mathrm{C}$ were recorded.

\subsection{Air}

Air samples were collected by the sedimentation technique (SVEUM et al., 1992), by exposing open Petri dishes containing plate count agar and potato dextrose agar (Merck Laboratories, Darmstadt, Germany) to the environment for 15 minutes, and then mesophilic aerobic bacteria and yeast/mold counts were made, respectively. The air of the following food service unit environments was sampled in both study phases: Utensils storage area ( $n=4$ rooms), food pre-preparation area $(n=4$ rooms), and preparation area $(\mathrm{n}=4$ rooms).

\subsection{Good working practices}

The results obtained from the questionnaire, microbiological evaluations, and each unit's documentation as well as observations of food handling practices were used to draw up an action plan that included the correction of noncompliance issues, training food handlers on good handling practices, and preparing a manual containing standardized operation procedures for integrated pest control, personal hygiene, hand washing, and hygienization of utensils, equipment, and food handling surfaces.

\subsection{Statistical analysis}

SPSS software (SPSS Inc, Chicago, version 17.0, 2008) was used to construct a database for variance analysis. The comparison between the data obtained in Phase 1 and Phase 2 was performed using the Wilcoxon test for unpaired data and the chi-square Fisher exact test.

\section{Results and discussion}

\subsection{Facilities and working practices evaluation}

The data obtained from the questionnaire and the direct observation of working practices for food production enabled us to evaluate the compliance of the food service unit with legislation requirements (Table 1 ).

The unit investigated was rated 'regular' in the overall evaluation, with $64.4 \%$ compliance with the state requirements. Sectors classified as 'poor' in the evaluation were: building facilities, equipment, utensils and furniture, and documentation and registration. Other aspects evaluated, such as integrated pest control, water supply, waste management, and display of prepared foods were in full compliance with technical and regulatory requirements. 
The section on operational records documentation, which serves to monitor good handling practices and auditing of food production, had $100 \%$ noncompliance rate. A similar result was found in another study on food service establishments in Southern Brazil suggesting that the lack of records documentation is a common occurrence in this region (SACCOL, 2007). The questionnaire results also revealed poor conditions of the building facilities, equipment, utensils, and furniture, which may undermine the goal of producing safe meals. Many Brazilian institutional food service operations are weak in this section of the evaluation either because their location is inappropriate or they make use of obsolete equipment, and therefore require modernization in infrastructure to ensure the production of safe meals (CARDOSO; SOUZA; SANTOS, 2005; RAMOS; SCATENA; RAMOS, 2008).

\subsection{Microbiological analysis}

The results of microbiological counts from processing equipment surfaces and environmental air of the food service unit obtained in the phases 1 and 2 are presented in Table 2 .

A reduction in the average counts of aerobic mesophilic bacteria, coliforms, and yeast/mold on equipment surfaces was found after the training and implementation of standardized working practices was completed although the differences were not statistically significant $(\mathrm{p}>0.05)$. Since there are no microbiological guidelines in Brazil for evaluating the hygienic status of food contact surfaces, we used aerobic mesophilic bacteria and yeast/mold counts of $\leq 50 \mathrm{CFU} . \mathrm{cm}^{-2}$ (satisfactory) and $>50$ CFU. $\mathrm{cm}^{-2}$ (unsatisfactory) as criteria for hygienic quality (BRASIL, 2001; SILVA JUNIOR, 2007). Based on these criteria, the results suggest that the action plan measures were effective in improving hygienic working practices in the food service unit.

Comparing the microbial average counts of the air in different working areas of the food service unit with the maximum limit of 30 viable particles $/ \mathrm{cm}^{2} /$ week recommended by American Public Health Association (APHA) for food industry environmental air (SVEUM et al., 1992), we found that the air cleanliness in these areas was not up to standard, and of a greater concern was the fact that it remained so even after the training and implementation of good practices. However, on a positive note, the mesophilic aerobic bacteria average counts in the air did significantly reduce $(p=0.02)$ in phase 2 of the study, and an increase in the percentage of samples compliant with APHA's recommendations was seen (25 to $81 \%, p=0.04)$. Similarly, the yeast/mold mean counts also decreased in phase 2 , and the percentage of samples compliant with the APHA's recommendations increased from 6.3 to $31.3 \%$; however, these were not statistically significant, $p=0.12$ and $\mathrm{p}=0.17$, respectively.

Table 1. Evaluation of working practices and facilities in an institutional food service unit in Southern Brazil according to state guidelines.

\begin{tabular}{|c|c|c|c|c|}
\hline Evaluation section $^{\star}$ & $\begin{array}{l}\text { Items evaluated } \\
\text { (n) }\end{array}$ & $\begin{array}{c}\text { Conforming to guidelines } \\
\mathrm{n}(\%)\end{array}$ & $\begin{array}{l}\text { Not conforming to } \\
\text { guidelines } \mathrm{n}(\%)\end{array}$ & Classification \\
\hline Building facilities, equipment, utensils and furniture & 32 & $21(34)$ & $11(66)$ & Poor \\
\hline Cleaning and sanitation procedures & 17 & $10(59)$ & $7(41)$ & Regular \\
\hline Food handlers' practices & 14 & $9(79)$ & $5(21)$ & Good \\
\hline Raw materials, ingredients and packaging & 12 & $9(75)$ & $3(25)$ & Regular \\
\hline Food preparation practices & 22 & $15(68)$ & $7(32)$ & Regular \\
\hline Display of prepared foods & 9 & $6(67)$ & $3(33)$ & Regular \\
\hline Operational records documentation & 3 & $0(0)$ & $3(100)$ & Poor \\
\hline
\end{tabular}

${ }^{*}$ State Decree 78 of January $30^{\text {th }}$, 2009, State of Rio Grande do Sul, Brazil.

Table 2. Microbiological counts in an institutional food service unit before and after training food handlers on good practices*.

\begin{tabular}{|c|c|c|c|c|c|c|}
\hline Microorganisms & Collection site & Samples (n) & Mean counts & Variation & Standard deviation & p-value $e^{\star * * * *}$ \\
\hline \multirow[t]{6}{*}{ Mesophilic bacteria } & Air** & & & & & \\
\hline & Phase $1^{\star * *}$ & 12 & 147 & 60 to $2 \times 10^{2}$ & 164 & 0.02 \\
\hline & Phase 2 & 12 & 92 & 20 to $4 \times 10^{2}$ & 95 & \\
\hline & Equipment surfaces ${ }^{* * * *}$ & & & & & \\
\hline & Phase 1 & 21 & 75 & $<1$ to $4 \times 10^{2}$ & 128 & 0.16 \\
\hline & Phase 2 & 21 & 44 & $<1$ to $5 \times 10^{2}$ & 147 & \\
\hline \multirow[t]{6}{*}{ Yeasts/molds } & Air & & & & & \\
\hline & Phase 1 & 12 & 164 & 90 to $4 \times 10^{2}$ & 85 & 0.12 \\
\hline & Phase 2 & 12 & 120 & 30 to $3 \times 10^{2}$ & 96 & \\
\hline & Equipment surfaces & & & & & \\
\hline & Phase 1 & 21 & 58 & $<1$ to $5 \times 10^{2}$ & 111 & 0.31 \\
\hline & Phase 2 & 21 & 33 & $<1$ to $4 \times 10^{2}$ & 117 & \\
\hline \multirow[t]{3}{*}{ Coliforms } & Equipment surfaces & & & & & \\
\hline & Phase 1 & 21 & 59 & $<1$ to $4 \times 10^{2}$ & 106 & 0.33 \\
\hline & Phase 2 & 21 & 18 & $<1$ to $2 \times 10^{2}$ & 48 & \\
\hline
\end{tabular}

${ }^{\star}$ Results are $\mathrm{CFU} / \mathrm{cm}^{2} /$ week for air and $\mathrm{CFU} / \mathrm{cm}^{2}$ for equipment surfaces. ${ }^{* *}$ Food pre-preparation and preparation rooms and utensils storage area. ${ }^{\star * *}$ Phase $1=$ Samples collected before training and implementation of good practices. Phase $2=$ Samples collected after training and implementation of good practices. ${ }^{* * * *}$ Meat cutting boards, vegetables cutting boards, pans, and food handling tables. ${ }^{* * * *}$ Wilcoxon test. 
Table 3. Bacterial counts on the hands of food handlers from an institutional food service unit in Southern Brazil pre-and post-good practices training.

\begin{tabular}{cccc}
\hline Good Practices Training & Food handlers $(\mathrm{n})$ & Coagulase-positive Staphylococcus $(\mathrm{CFU} / \mathrm{hand} \pm \mathrm{SD})$ & Coliforms $(\mathrm{CFU} / \mathrm{hand} \pm \mathrm{SD})$ \\
\hline Pré-implementation & 19 & $82.2 \pm 44^{*}$ & $11.6 \pm 8^{\star *}$ \\
Post-implementation & 19 & $25.7 \pm 21^{\star}$ & $0.5 \pm 0^{\star *}$ \\
\hline
\end{tabular}

${ }^{*} \mathrm{p}=0.12$ (Wilcoxon test for unpaired data). ${ }^{* *} \mathrm{p}=0.04$ (Wilcoxon test for unpaired data.

One of the major reasons for the sub-standard air quality could be attributable to deficiencies in the infrastructure, such as lack of physical barriers between the food storage, cleaning, and preparation areas that facilitates the flow of air from external contaminated areas. Another factor for high microbial counts could be the fact that the air samples were collected during food production time.

When it came to water quality, mesophilic bacteria counts were $<1$ UFC. $\mathrm{mL}^{-1}$, and coliforms were absent in all water samples $(\mathrm{n}=32)$ tested in study phases 1 and 2 (data not shown), which were in compliance with the water standards established by Brazilian legislation (BRASIL, 2004).

Coliform bacteria and coagulase-positive staphylococci counts are important indicators of food safety, and counting these bacteria on food handlers' hands is widely used in monitoring proper hand hygienization practices. Table 3 shows the average counts of these bacteria on the hands of food handlers before and after training and implementation of good working practices.

Coliform counts were significantly reduced $(\mathrm{p}<0.05)$ and coagulase-positive staphylococcus counts also decreased, although not significantly $(p>0.05)$. These results show a significant improvement in hand hygiene in phase 2 , a testament to the efficacy of the plan of action measures.

Food handlers are one of the major sources of food contamination with staphylococci and coliforms because these organisms naturally colonize the upper respiratory tract, skin surface, and gastrointestinal tract of humans. It is virtually impossible to prevent their presence in foods that are handled. Nevertheless, this study has shown that staff training effectively improves the hygienic quality of foods prepared in institutional food services, and that microbiological monitoring is an appropriate tool to evaluate the use of good working practices.

\section{Conclusions}

The institutional food service unit studied was classified as regular according to state safety guidelines for food service establishments with major deficiencies in building facilities and operational records documentation. The water available for use in food production was within the parameters outlined by the Brazilian guidelines. Hygienic quality of equipment surfaces, food handling areas, and food handlers' hands improved after training and implementation of good working practices. Microbiological testing was shown to be a useful tool for monitoring the implementation of the HACCP prerequisite program.

\section{References}

BENNETT, R.W.; LANCETTE, G. A. Staphylococcus aureus. In: ASSOCIATION OF OFFICIAL ANALYTICAL CHEMISTS AOAC. Bacteriological analytical manual, 8th ed. Gaithersburg: AOAC, 1998. cap. 12, p. 1-5.

BRASIL. Ministério da Saúde. Agência Nacional de Vigilância Sanitária. Resolução no 12, de 02 de janeiro de 2001. Aprova o Regulamento Técnico sobre Padrões Microbiológicos para Alimentos. Diário Oficial da República Federativa do Brasil, Brasília, DF, 02 de jan. 2001.

BRASIL. Ministério da Saúde. Agência Nacional de Vigilância Sanitária. Portaria no 518 de 25 de março de 2004. Procedimentos e responsabilidades relativos ao controle e vigência da qualidade da água para consumo humano e seu padrão de potabilidade. Brasília: Ed. do Ministério da Saúde, 2005. (Série E. legislação em saúde). Disponível em: <http://bvsms.saude.gov.br/bvs/publicacoes/ portaria_518_2004.pdf/>. Acesso em: 8 maio 2010.

CARDOSO, R. C. V.; SOUZA, E. V. A.; SANTOS, P. Q. Unidades de alimentação e nutrição nos campi da Universidade Federal da Bahia: um estudo sob a perspectiva do alimento seguro. Revista de Nutrição, v. 18, n. 5, p. 669-680, 2005. http://dx.doi.org/10.1590/ S1415-52732005000500010

CARMO, G. M. I. Vigilância epidemiológica das doenças transmitidas por alimentos no Brasil. Brasília: Secretaria de Vigilância em Saúde, 2008. Disponível em: <http://www.anvisa. org.br>. Acesso em: 10 mai. 2010.

CODEX ALIMENTARIUS COMISSION. Hazard analysis and critical control point (HACCP) system and guidelines for its application. In: CODEX ALIMENTARIUS COMISSION. General requirements (food hygiene). Roma: Codex Alimentarius Comission, 1997. Disponível em: <http://www.haccphelp.com/Documents/Codex. pdf $>$. Acesso em: 11 jun. 2010.

HITCHINS, A. D. et al. Escherichia coli and the Coliform Bacteria. In: AOAC International. Bacteriological analytical manual. 8th ed. Gaithersburg: AOAC, 1998. cap. 4, p. 1-29.

MAURIN, L. J.; PEELER, J. T. Aerobic plate count. In: ASSOCIATION OF OFFICIAL ANALYTICAL CHEMISTS - AOAC. Bacteriological analytical manual. 8th ed. Gaithersburg: AOAC, 1998. cap. 3, p. 1-10.

OLIVEIRA, S. P. et al. Condições higiênico-sanitárias do comércio de alimentos do município de Ouro Preto, MG. Higiene Alimentar, v. 19, n. 136, p. 26-31, 2005.

RAMOS, M. L.; SCATENA, M. F.; RAMOS, M. I. L. Qualidade higiênico-sanitária de uma unidade de alimentação e nutrição institucional de Campo Grande, MS. Higiene Alimentar, v. 22, n. 164, p. $25-31,2008$.

RIO GRANDE DO SUL (Estado). Secretaria Estadual da Saúde. Portaria $n^{\circ} 78$, de 28 de janeiro de 2009. Lista de verificação em boas práticas para serviços de alimentação e normas para cursos de capacitação em boas práticas para serviços de alimentação. Disponível em: <http://www.sinurgs.org.br/docs/35.pdf/>. Acesso em: 11 jun. 2010. 
SACCOL, A. L. F. Sistematização de ferramenta de apoio para Boas Práticas em Serviços de Alimentação. Santa Maria, 2007. 192 f. Dissertação (Mestrado em Ciência e Tecnologia de Alimentos)Universidade Federal de Santa Maria, Santa, 2007.

SILVA JUNIOR, E. A. Manual de controle higiênico-sanitário em serviços de alimentação. São Paulo: Varela, 2007.

SVEUM, W. et al. Microbiological monitoring of the food-processing environment. In: VANDERZANT, C.; SPLITTSTOESSER, D. F.; SPECK, M. L. (Ed.). Compendium of methods for the microbiological examination of foods. 3. ed. Washington: American Public Health Association, 1992. cap. 3, p. 51-74.

TOURNAS, V. et al. Yeasts, Molds and Mycotoxins. In: ASSOCIATION OF OFFICIAL ANALYTICAL CHEMISTS - AOAC. Bacteriological analytical manual. 8th ed. Gaithersburg: AOAC, 1998. cap. 18, p. 1-11.

WORLD HEALTH ORGANIZATION. Food borne disease outbreaks: guidelines for investigation and control. 2008. Disponível em: $<$ www.who.int/foodsafety/publications/foodborne_disease/ fdbmanual/index.html>. Acesso em: 17 fev. 2010. 